\title{
Puchon 2008
}

\author{
By Ron Holloway
}

Fall 2008 Issue of KINEMA

\section{PUCHON INTERNATIONAL FANTASTIC FILM FESTIVAL 2008}

Asked by by a Korean colleague if I would be willing to serve on the international jury for the $12^{\text {th }}$ Puchon International Fantastic Film Festival (7-18 July 2008) - "PiFan" for short - I responded that I wasn't quite sure what a "fantastic" film is in the first place. Not a problem, he said, for he had heard that grouse often enough before. As it turned out, when I arrived at this bustling satellite city on the outskirts of Seoul (now known officially as Bucheon instead of Puchon), there, above a prominent "PiFan" logo, was a banner that highlighted "Love, Fantasy and Adventure" as the festival's all-embracing theme. Further, in PiFan's 200-page catalogue you could find concisely penned film notes that underscored the fantastic elements in 215 films from 39 countries, including 17 world premieres and 15 international premieres. Indeed, there is and certainly always was - such a phenomenon as the fantastic film. I just hadn't been paying close enough attention.

First and foremost, PiFan is a genre festival. And, as the leading genre film festival in Asia, it's dedicated to the concept of screening the breadth of popular movie fare. According to festival director Han Sang Jun, "PiFan programs a diverse slate of films of unique forms and styles that go beyond the realms of existing fantastic genre, in addition to choosing the latest domestic and international horror, thriller, mystery and fantasy films to satisfy dedicated fans of fantastic genre films." One glance at this year's selection, and you can easily pigeonhole nearly all of the entries invited to PiFan 2008 into one or more of six overlapping genres: fantasy, horror, animation, thriller, cult, and science-fiction. Further, PiFan's programming finesse keeps the viewer guessing when and where the "fantastic" just might pop up in the middle of a plot or elsewhere along the cutting edge of narrative cinema.

This year, despite heavy rains throughout the festival, PiFan's "genre feast" drew a reported attendance of 58,721 paid admissions, with 81 of the 270 total screenings sold out. These, in addition to free passes given to 1978 official guests - a record number for PiFan, the attendance abetted by the festival's first project market, called the Network of Asian Fantastic Films (NAFF2008). Since two additional days were tagged onto the schedule in order to accommodate fans who wanted to catch up on awarded films and popular hits, the overall 12-day festival attendance figure easily passed the 60,000 mark (although 80,000 had been originally anticipated).

To accommodate the overflow of guests, regular shuttle service was provided from the festival headquarters at the Koryo Hotel to five nearby venues: the brand new Primus Cinema Complex in the Sopoooong Shopping Mall, plus screening facilities at the Hyundai Department Store, Boksagol Cultural Centre, Bucheon City Hall, and Bucheon Citizens Hall. Moreover, should a visitor got lost, there were 400 volunteers (the Pusan International Film Festival, by the way, has 700 volunteers!), all outfitted in red blazers, to point the way not just to the venues, but also to event sites and the so-called "PiFan DC Zone" - to wit: discount cafes for accredited guests.

\section{Korean Film Festivals}

Another PiFan initiative of immense importance to boost its genre movie image was the continual presence of Korean film and media personalities at major events throughout the festival. This year, the attractive and popular Kim Yu Jin (aka Kim Eugene) was elected "PiFan Lady" to grace receptions and parties - and she fit the bill neatly. When I asked the Korean pop-and-film star how it was that she could speak American English without an accent, "Eugene" challenged me with an plucky question of her own: "Do you know where Guam is? I was born and raised there as a child."

Another personal pleasure was meeting Nelson Shin, the legendary Korean animation director, who had spent eight years making the animated feature Empress Chung (2005), the first film to be co-produced and simultaneously released in North and South Korea. An epic cartoon adventure based on a Korean folk tale, Empress Chung is about a girl who sacrifices herself in order to restore her blind father's eyesight. 
On a visit to his AKOM Studio in Seoul, I asked Nelson Shin about his long-standing collaboration with DePatie-Freleng Enterprises (DFE) in Los Angeles, famous for the Pink Panther series. Although he enjoyed talking about Fritz Freleng and his fruitful Hollywood apprenticeship, we spent more time chatting about his contribution to The Simpsons cartoon phenomenon. "I feel very much attached to that series since I'm doing it now for 20 years."

Nelson Shin also attended PiFan in his capacity as President of ASIFA Korea and Vice-President of ASIFA International, the International Animated Film Association. In this capacity he was instrumental in founding in 1997 the Seoul International Cartoon Animation Festival (SICAF), scheduled annually in April. Last April, SICAF screened 400 films, invited 200 guests, and drew an attendance of 41,000. The festival focus on animation not just for its visual content, but also as part of the developing digital contents industry. Another Seoul festival director present at PiFan was Lee Hyae-Kyoung, who heads the International Women's Festival in Seoul (WFFIS). Founded in 1997 and programmed annually in April, the last WFFIS screened 73 films and drew an attendance of 33,000. Kim Dong Ho, the director of the Pusan International Film Festival (PIFF), was also on hand. Founded in 1995, scheduled annually in October, and generally recognized as the world's key Asian film festival, PIFF 2007 programmed 275 films from 64 countries. It's significant to note that all four of these festivals have benefited from the popularity of its partners. Shortly after PIFF was founded in 1995, along came PiFan in 1996, then SICAF and WFFIS in 1997.

\section{On and Off Fantastic}

For the cineaste, PiFan's lineup of sidebars are festivals within the festival. Among the 30 films booked for World Fantastic Cinema section were entries from Europe, Far East, Down Under, North and South America. Among these was Nic Balthasar's Ben X (Belgium), the top award winner at last year's Montreal World Film Festival, in which a lad living a virtual existence as an online gamer regularly logs on to a Korean video game - recognized immediately by the Puchon public! Another audience favourite were the fast-paced song-and-dance numbers in Farah Kahan's Om Shanti Om (India), the runaway blockbuster hit starring screen idol Shah Ruah Khan in a fantasy-filled reincarnation melodrama.

PiFan aficionados also applauded the newly launched Strange Homage section, billed as a "Hall of Honor" to pay homage to past and present masters of fantastic cinema. Programmed in the six-pack was a restored black-and-white print of Kim Ki Young's legendary The Housemaid (Korea, 1960). A Buñuel-like satire on the bourgeoisie, it features a femme fatale housemaid out to seduce a musician and destroy both him and his family. Also, in Tom Kalin's Savage Grace (USA-Spain-France), programmed at the 2007 Cannes festival in the Directors Fortnight, Juliane Moore gives one of her best screen performances as Barbara Daly in the Baekeland family murder that took place in 1972 in a posh London flat. In a film that unwinds in six acts over 36 years, from 1946 to 1972, the lovely Juliane Moore mysteriously never seems to age!

Genre cinema had a field day in the Off the Fantastic section. Here, 20 entries explored the contrasting cultural avenues of classic genre cinema, from Hollywood impersonators in David J. Markey's The Reinactors (USA) to an Asian contest for the best tea flavour and aroma in Yeming Wang's Tea Fight (Japan-Taiwan). An audience favourite was Andreas Dresen's Wolke 9 (Cloud 9, Germany), the Cannes festival hit in which a casual liaison between an elderly pair - he in his mid-seventies, she in her mid-sixties - leads eventually to a tragic misunderstanding in the woman's family life. The section also spotlighted James Westby's kinky The Auteur (USA), a tongue-in-cheek comedy about a renown porn director on his way to Portland to receive a Lifetime Achievement Award! Part soft porn, part B-movie trash, The Auteur echoes the jo-jo career and pseudo aesthetics of famed director Edward D. Wood, the cult king of "turkey" classics.

For many visitors, PiFan would not be deemed a genuine fantastic film festival at all without its Forbidden Zone, a four-entry section with a see-it-if-you-dare program of way-out splatterfest films that scorn conventions and taboos in pursuit of radical expression and subversive thought. The titles of these low-budget ghoul fantasies speak for themselves: Yoshihiro Nishimura's Tokyo Gore Police (Japan), Percy Limon's Doctor Hell, the Movie (Spain), Robert Kurtzman's The Rage (USA), and Klaus Hundsbichler's World Revolution (Austria). Nishimura's Tokyo Gore Police, a violent, gore-spilling, stomach-crunching SFXer about a futuristic woman police officer assigned to eliminate a virus that turns humans into mutants, received a Special Mention by the jury for the European Federation of Fantastic Film Festivals (EFFFF) Asian Award.

\section{Fanta and Fantasies}


To balance out its programming ledger, PiFan annually offers its public an international survey of fantastic films for children of all ages. Not surprisingly, in view of PiFan's guaranteed SRO audiences, some filmmakers have even opted to preview their new productions here before the official release at home. In the Family Fanta section, for instance, you could catch a preview of Lourens Blok's heralded De Zeven van Daran (The Seven of Daran, Netherlands), a safari-style fantasy film with both feet on the ground. In The Seven of Daran, about a shy Dutch lad on a trip to Africa with his mother, the youth is weaned away from his video game when he meets a talking giraffe - who, in turn, enlists his help to resolve a tribal conflict in the jungle together with a young African girl.

Similarly, Kwak Jae Yong's Boku no kanojo wa saibogu (Cyborg She, Korea-Japan) successfully celebrated its world premiere as the closer at this year's PiFan festival. The story of an impudent, eccentric cyborg (Japanese actress Keisuke Koide), who time-travels from the future back to 2007 to rescue an awkward college student from troublesome messes he keeps getting into, the scifi-er feeds off a range of familiar yet still proven slapstick gags. Kwak's Cyborg She is the third film in the Korean director's popular "weird chick" trilogy that began with Yeopgijeogin geunyeo (My Sassy Girl, Korea, 2001) and continued as a box office attraction with Nae yeojachingureul sogae habnida (Windstruck, Korea-Hongkong, 2004).

A quartet of entries in the festival's Ani Fanta section confirmed that the animated feature film is currently on a roll. Tops on the list was the world premiere of John Bergin's From Inside (USA), a dark apocalyptic tale with sorrowful overtones as already underscored in the filmmaker's screen-adapted graphic novel. Set on a moving train, a young pregnant woman passes through a dark, surreal, nightmarish world of death and ruin as she wrestles with the memory of her dead husband and the pangs of approaching childbirth. The film's epic dimensions, reinforced by a dusky 3-D image and a Goth-rock soundtrack, signal a new direction in the American animated feature film.

Pretty much the same praise can be showered on the film that opened the PiFan festival: Israeli director Ari Folman's extraordinary Waltz With Bashir (Israel-France-Germany), a feature-length animated documentary film. One of the most discussed films at the Cannes film festival, Waltz With Bashir tackles a tabu theme never treated before in Israeli media: the apparent Israeli complicity in the June 1982 massacre of hundreds of Palestinian civilians by Lebanese Phalangists in the Beirut refugee camps of Sabra and Shatila.

Besides these traditional sections in the festival portfolio, the PiFan staff added an extra bundle of seven Special Programs to fatten out the schedule. Some of these programs were cited in the catalogue with caveats for viewing caution. "Q-Rious" programmed films with contradictions, conflicts, and antimony. "The Rebellious" was subtitled as an Asian Action Special. "The Grindhouse Revisited" left little doubt as to its thematic content, but under "Code Name: Korean Hwalgeuk in Tri-Asia" the code name refers to "action movies" in Korean. "Fanta Masters" saluted American cult director Greg Araki in a four-film retrospective. Among the six contemporary Russian films programmed in "Chills From the Cold Land" was Khuat Akhmetov's Chelovek-veter (Wind Man, Russia), a comic allegory about a fallen angel in the Kazakh steppe. And "100 Years of Nikkatsu: Inventions and Challenges" celebrated the centennial of the Japanese Studio with a retrospective of eight fantastic films dating from 1934 to 2008, with particular reference to films produced during the 1960s and 1970s.

\section{PiFan Choices}

Besides the prizes awarded by international juries in the Puchon Choice Features competition and the Puchon Choice Shorts competition (both 12 entries), a third Asian Award was given by a jury chosen from members of the European Federation of Fantastic Film Festivals (EFFFF). Further, the Puchon audience participated with two Prugio Citizens Choice Awards.

Na Hong Jin's crime thriller Chugyeogja (The Chaser, Korea) bagged three PiFan awards. Besides its twofold award citation - the "Best of Puchon" Choice Award by the international jury and EFFFF Asian Award by the European Federation of Fantastic Film Festivals - Seo Yeong Hee was awarded Best Actress for her fine performance as the sympathetic single-mother prostitute victimized by a lunatic killer in Na's The Chaser. The story of an ex-detective-turned-pimp chasing a psychopathic serial killer, whose trail of murders is difficult to trace despite admitted guilt under police questioning, The Chaser was invited to Cannes last May for an out-of-competition midnight screening. According to a recent report, Warner Bros has paid $\$ 1$ million to purchase the remake rights. 
Another double winner at PiFan, Tomas Alfredson's Låt den rätte komma in (Let the Right One In, Sweden) was awarded Best Director by the international jury in addition to receiving the Prugio Citizens Choice Award. A fantasy film drawing on traditional vampire motifs, Let the Right One In is the story of a shy lad who silently bears bullying at school - until a new friendly neighbour, who happens to be an ageless vampire teenager, steps in to help him. Lina Leandersson as the vulnerable vampire gives a disarming performance.

Ekin Cheng and Shawn Yue were jointly awarded Best Actors for their performances in Kelvin Tong's Rule Number One (Hong Kong-Singapore), an action thriller wedded to the ghost-horror genre. When two police detectives in the Miscellaneous Affairs Department (MAD) pursue a maniac killer, they discover that he can also contaminate victims with a virus that turns them into blood-thirsty killing machines. Shot in Hong Kong, Rule Number One is enhanced by the presence of two popular Hong Kong actors appearing in the same movie. Ekin Cheng (a former Cantopop singer known earlier in his career as "Noodle Cheng") plays the older sceptical detective, partnered with Shawn Yue (a full time model before his rapid rise as a Hong Kong matinee idol) as the newcomer who has to learn firsthand the "number one rule" of the MAD code: don't believe in ghosts!

The Jury Choice Award (aka Special Jury Prize) was given to the lone animation feature in the competition: Peur(s) du noir (Fear(s) of the Dark, France), co-directed by Blutch (Christian Hincker), Marie Caillou, Pierre de Sciullo, Jerry Kramski, Lorenzo Mattoti, Richard McGuire, Michel Pirus, and Romain Slocombe. A collection of six interlocking black-and-white animated shorts, Fear(s) of the Dark stems from an idea by the French graphic-design company Prima Linea to enlist talented artists from the world of comics and graphic art to explore our primordial fear of all things dark. In Marie Caillou's manga-inspired episode a traumatized Japanese schoolgirl relives a shocking incident at the hands of a doctor sticking needles in her arm. And in Richard McGuire's haunted-house episode, simple black-and-white lines are eerie enough to suggest the fright many feel of sleeping in the dark.

Purse awards were handed out in the Puchon Choice Shorts competition. Rodrigo Gudino won $\$ 5,000$ for The Facts in the Case of Mister Hollow (Canada), a six-minute short about how a photo can reveal salient facts about missing children. Chang Hyung-yun won $\$ 5,000$ for his animated A Coffee Vending Machine and Its Sword (Korea), a charming modern-day fairy tale about a slain swordsman reincarnated into a vending machine who repays the kindness of being cared for by a young girl. The 30-minute short was also voted the Prugio Citizens Choice Award. The Jury Choice Award (aka Special Jury Award), with its $\$ 3,000$ purse, went to Christian Klandt's Schausteins letzter Film (Schausteins Final Film, Germany), a neatly constructed 30-minute fairy tale about an netherworld gnome searching for an old projectionist's "final film" so that the dying man can see his entire life running before his eyes as he bids farewell to his human coils.

\section{NAFF2000}

For the first time, PiFan launched a five-day Project Market under the banner Network of Asian Fantastic Films. Titled NAFF2008, its main section - "It Project" - was designed to provide an impetus to Asian genre cinema by encouraging the development and financing of officially selected genre projects in various stages of production. Programmed by Kwon Yong-min, 16 projects from eight countries were presented for consideration, from which a three-person international jury selected four films for completion, each receiving US $\$ 10,000$ in production support.

Two of the winners were Korean projects: Kim Jin-won's The Devils, a horror movie, won the PiFan Award. Chang Hyung-yun's My Girlfriend Is a Brindled Cow, an animated comedy, won the NAFF Award. Further, Frank Lin's ODB (USA), a hip-hop scifi-er, won the Puchon Award, and Zhang Yong's Bomb Shelter (China), a ghost mystery, won the XTM Extreme Project Award. In addition five films won post-production support, each receiving US $\$ 5000$ each. Xie Dong's 206 Speed Delivery (China) and Nathan Adolfson's The Help (Philippine-USA) jointly won the Moneff Award for Editing. Kevin Ko's Starstruck (Taiwan) and Kim Jinwon's The Devils (Korea) jointly won the Digital Cinemeka Award for CG Production. And Kim Hong-suk's Removal (Korea) won for Best Sound.

Further, 168 industry professionals from 13 countries took part in NAFForum meetings to exchange concrete ideas for development of the genre film industry. More than 200 official meetings took place, with the greatest interest shown for the aforementioned $0 D B$, Removal, and Starstruck. Fans of genre cinema could also attend workshops at the Fantastic Film School with Seoul Action School directors Jung Doo-hong and 
Jung Chang-hyun. The School also organised an Action Screenwriting Lab with director Kim Jin sung, an Action Shooting Workshop with cinematographer Kim Hyung-gu, and an Action Editing Analysis Lab with directors Kim Tae-kyun, Kwak Kyung-taek, and Lee Myung-se, joined by journalist Joo Sung-cheol, known for his action film expertise and DVD commentaries in the genre.

\section{References}

Puchon Choice Awards

Feature Competition

Best of Puchon Award

Chugyeogja (The Chaser, Korea), dir Na Hong Jin

Best Director

Tomas Alfredson, Låt den rätte komma in (Let the Right One In, Sweden)

Best Actor - ex aequo

Ekin Cheng, Shawn Yue, Rule Number One (Hong Kong-Singapore), dir Kelvin Tong

Best Actress

Seo Yeong Hee, Chugyeogja (The Chaser, Korea), dir Na Hong Jin

Jury Choice Award

Peur(s) du noir (Fear(s) of the Dark, France), dir Blutch, Marie Caillou, Pierre de Sciullo, Jerry Kramski, Lorenzo Mattoti, Richard McGuire, Michel Pirus, Romain Slocombe.

Prugio Citizens Choice Award

Lät den rätte komma in (Let the Right One In, Sweden), dir Tomas Alfredson

Shorts Competition

Puchon Choice Shorts Award

The Facts in the Case of Mister Hollow (Canada), dir Rodrigo Gudiño

Jury Choice Award

Schausteins letzter Film (Schausteins Final Film, Germany), dir Christian Klandt

Best Korean Shorts Award

A Coffee Vending Machine and Its Sword, dir Chang Hyung Yun

Puchon Citizens Choice Award

A Coffee Vending Machine and Its Sword (Korea), dir Chang Hyung Yun

European Federation of Fantastic Film Festivals (EFFFF) Asian Award

Chugyeogja (The Chaser, Korea), dir Na Hong Jin

Special Mentions - for Excellence in Fantasy Art Direction

Hansel $\&$ Gretel (Korea), dir Yim Phil Sung

Tokyo zankoku keisatsu (Tokyo Gore Police, Japan), dir Yoshihiro Nishimura

\section{Author Information}

Ron HOLLOWAY (1933-2009) was an American critic, film historian, filmmaker and correspondent who adopted Europe as his home in the early fifties and spent much of his life in Berlin. He was an expert on the study of German cinema and against all odds produced, with his wife Dorothea, the journal German Film, keeping us up-to-date with the work of directors, producers and writers and the showing of German films around the world.

In 2007, Ron Holloway and his wife were awarded the Berlinale Camera Award. Ron also received the Bundesverdienstkreuz (German Cross of Merit), Polish Rings, Cannes Gold Medaille, the American Cinema 
Foundation Award, the Diploma for Support of Russian Cinema and an honorary award from the German Film Critics' Association.

Ron was also a valued contributor to Kinema for the past fifteen years. 